\title{
Uji Daya Hambat Bakteri Escherichia Coli pada Produk Hand Sanitizer
}

\author{
Sumarsih ${ }^{1}$, \\ 1Universitas Muhammadiyah Yogyakarta, Bantul, 55181,email: sumarsih1506@gmail.com
}

Submisi: 30 Juli 2021; Penerimaan: 30 Agustus 2021

\begin{abstract}
This study was aimed to determine the inhibition of Escherichia coli bacteria in hand sanitizer products. The methode used in this study was a single factor Completely Randomized Design (CRD) experimental methode using 3 treatment variables and repeated three times. The treatments tested were the addition of $98 \%$ glycerol and $3 \% \mathrm{H}_{2} \mathrm{O}_{2}$ to hand sanitizers with chemicals as well as the addition of aloe vera gel and lime essential oil to hand sanitizer products with natural ingredients compared to commercial hand sanitizer products as controls. The parameters observed was the diameter of in the inhibition zone of Escherichia coli bacteria. Analysis of the research data using the 5\% ANOVA variance analysis technique and Duncan's Multiple Range Test (DMRT) further test for those significantly different treatments. The results shows that commercial hand sanitizer products had a greater inhibitory power of Escherichia coli bacteria than hand sanitizer products with chemicals or hand sanitizers with homemade natural ingredients.
\end{abstract}

Keywords: Hand Sanitizer; inhibition; chemicals; aloe vera gel; Escherichia coli

\begin{abstract}
ABSTRAK
Penelitian ini bertujuan untuk mengetahui daya hambat bakteri Escherichia coli pada produk hand sanitizer. Metode yang digunakan pada penelitian ini adalah metode eksperimen Rancangan Acak Lengkap (RAL) faktor tunggal menggunakan 3 variabel perlakuan dan tiap perlakuan diulang tiga (3) kali. Perlakuan yang diujikan adalah penambahan gliserol $98 \%$ dan $\mathrm{H}_{2} \mathrm{O}_{2} 3 \%$ pada hand sanitizer dengan bahan kimia serta penambahan gel aloe vera dan esensial oil jeruk nipis pada produk hand sanitizer dengan bahan alami dibandingkan dengan produk hand sanitizer komersial sebagai kontrol. Parameter yang diamati merupakan diameter zona hambat bakteri Eschericia coli. Analisis data hasil penelitian menggunakan teknik analisis sidik ragam ANOVA 5\% dan uji lanjut Duncan's Multiple Range Test (DMRT) untuk perlakuan yang berbeda nyata. Hasil penelitian menunjukkan bahwa produk hand sanitizer komersial memiliki daya hambat bakteri Escherichia coli yang lebih besar dibandingkan dengan produk hand sanitizer dengan bahan kimia maupun hand sanitizer dengan bahan alami buatan sendiri.
\end{abstract}

Kata kunci: Hand sanitizer; daya hambat; bahan kimia; gel aloe vera; Escherichia coli

\section{PENDAHULUAN}

Virus corona yang menyerang dunia pada awal tahun 2020 tak terkecuali Indonesia mengakibatkan kerugian di berbagai bidang antara lain pada sektor ekonomi dan kesehatan. Pemerintah membuat 
kebijakan dengan menganjurkan masyarakat Indonesia melakukan $3 \mathrm{M}$ yaitu memakai masker, mencuci tangan, menjaga jarak dan mengurangi kegiatan di luar rumah sebagai upaya pencegahan penyebaran virus corona ini. Sabun dan hand sanitizer menjadi kebutuhan pokok dalam upaya menjaga kebersihan tangan, dimana kedua bahan ini memiliki efektifitas masing-masing dalam melemahkan bahkan membunuh virus corona dengan komposisi kimia yang ada didalamnya (Lusiana et al., 2020).

Hand sanitizer adalah cairan antiseptik sebagai pengganti sabun pada saat tidak tersedianya air dan sabun untuk membersihkan tangan. Aktivitas masyarakat saat ini yang semakin tinggi dalam berbagai kegiatan menimbulkan keinginan dalam membersihkan tangan dengan cara yang praktis dan metode sanitasi ini bisa menjadi pilihan yang nyaman bagi masyarakat. Bahan utama dalam pembuatan hand sanitizer adalah alkohol yang berfungsi sebagai antiseptik untuk membunuh virus dan bakteri (Lusiana et al., 2020).

Penggunaan hand sanitizer dapat menghambat perkembangan bakteri bahkan memiliki kemampuan membunuh bakteri secara cepat dikarenakan kandungan senyawa kimia yang terkandung didalamnya antara lain alkohol, baik dalam bentuk etanol, propanol maupun isopropanol pada konsentrasi $60 \%$ hingga $80 \%$, triklosan dan juga golongan fenol yang berupa klorheksidin (Aminah. et al, 2018). Komponen senyawa-senyawa ini mempunyai kemampuan merusak protein yang ada pada sel kuman kemudian mengkoagolasinya (Baizuroh. et al, 2021).
Fungsi utama alkohol pada hand sanitizer adalah sebagai antiseptik yang digunakan pada permukaan kulit yang bersih. Penggunaan antiseptik merupakan langkah penting sebagai upaya pencegahan terjadinya infeksi yang berfungsi untuk melenyapkan mikroba (Nelintong et al., 2015). Infectious disease (penyakit infeksi) adalah penyakit yang timbul akibat adanya mikroorganisme patogen seperti virus, bakteri, parasit, dan jamur (Susanty. et al, 2020). Akan tetapi pemakaian alkohol secara berulang sebagai pembersih tangan kurang aman terhadap kesehatan kulit. $\mathrm{Hal}$ ini disebabkan alkohol adalah bahan kimia yang memiliki sifat mudah terbakar serta pada pemakaian berulang dapat mengakibatkan kulit menjadi kering ataupun iritasi pada kulit. Sebagai upaya penggunaan alkohol agar tetap efektif tanpa menimbulkan efek samping bagi penggunanya, maka dapat ditambahkan zat aditif dari bahan alami, seperti aloe vera (lidah buaya) untuk mengurangi iritasi pada kulit (Lusiana et al., 2020).

Aloe vera (lidah buaya) adalah tanaman yang mempunyai khasiat untuk menjaga kesehatan kulit. Tanaman ini memiliki keistimewaan pada gelnya yang mampu meresap di dalam jaringan kulit sehingga bisa menahan kehilangan cairan yang terlalu banyak dari dalam kulit. Beberapa senyawa yang terkandung pada gel aloe vera antara lain flavonoid, saponin, tanin dan polifenol yang mempunyai aktivitas sebagai antiseptik. Gel aloe vera memiliki kandungan 17 asam amino yang penting bagi tubuh. Aloe vera ini disebut tanaman multikhasiat karena kandungan senyawa yang ada didalamnya yaitu berupa emodin, aloin, lignin, resin, saponin, antrakuinon, 
vitamin, mineral, dan lain sebagainya. Dalam industri aloe vera dapat diolah menjadi gel, serbuk maupun ekstrak (Susanty. et al, 2020).

Penggunaan hand sanitizer semakin meningkat di kalangan masyarakat, terutama setelah virus corona menyerang di berbagai belahan dunia. Berbagai kalangan masyarakat membuat produk hand sanitizer baik yang digunakan sendiri maupun yang dijual belikan dengan bahan kimia maupun dengan penambahan zat aditif dari bahan alami seperti aloe vera. Hal ini yang menjadi dasar penelitian dengan judul Uji Daya Hambat Bakteri Escherichia coli pada Produk Hand Sanitizer.

\section{METODE PENELITIAN}

\section{Alat Penelitian}

Alat yang digunakan: pisau, blender cosmos, sendok pengaduk, saringan, corong, wadah kemasan, gelas ukur, beker gelas, timbangan analitik ohaus, cawan petri, autoklaf all american, mikropipet eppendorf, mikro tip, laminar air flow, vortex boeco, bunsen, jarum ose, cork borer dan jangka sorong.

\section{Bahan Penelitian}

Bahan yang digunakan: alkohol $96 \%$, hidrogen peroksida $3 \%$, gliserol $98 \%$, akuades, esensial oil, gel aloe vera, media nutrien agar, larutan $\mathrm{NaCl}$ 0,9\%, kultur bakteri Escherichia coli.

\section{Rancangan Percobaan}

Dalam penelitian ini rancangan percobaan yang dipakai adalah Rancangan Acak Lengkap faktor tunggal menggunakan tiga (3) variabel perlakuan dan tiap perlakuan diulang tiga (3) kali. Perlakuan yang diterapkan adalah variasi Hand sanitizer (HS) ditunjukkan pada Tabel 1.

Tabel 1. Perlakuan yang Diterapkan

\begin{tabular}{cccc}
\hline \hline Perlakuan yang Diterapkan & Komponen utama & Tambahan zat pelembab & Komponen tambahan lain \\
\hline \hline $\begin{array}{c}\text { A } \\
\text { (HS dengan bahan kimia) } \\
\text { B }\end{array}$ & Alkohol 70\% & Gliserol 98\% & H2O2 3\% \\
$\begin{array}{c}\text { (HS dengan bahan alami) } \\
\text { C }\end{array}$ & Alkohol 70\% & Gel aloe vera & Esensial oil jeruk nipis \\
(Kontrol/HS komersial) & Alkohol 70\% & - & aroma jeruk nipis \\
\hline
\end{tabular}

Hipotesis yang diuji pada penelitian ini adalah mengetahui daya hambat produk hand sanitizer terhadap bakteri Escherichia coli. Produk hand sanitizer dengan bahan kimia diduga mempunyai daya hambat bakteri Escherichia coli yang lebih besar dibandingkan dengan hand sanitizer dengan bahan alami. Data hasil penelitian dianalisis memakai teknik analisis sidik ragam ANOVA pada $\alpha=$ $5 \%$ dan uji lanjut Duncan's Multiple Range Test (DMRT).

\section{Proses Pembuatan Hand Sanitizer dengan Bahan Kimia}

Proses pembuatan hand sanitizer dengan bahan kimia adalah (1) Alkohol 96\% sebanyak 416,665 ml; Gliserol 98\% sebanyak 7,25 ml; Hidrogen peroksida $\left(\mathrm{H}_{2} \mathrm{O}_{2}\right) 3 \%$ sebanyak $20,85 \mathrm{ml}$; Akuades $500 \mathrm{ml}$ disiapkan dan dimasukkan pada wadah yang bersih. (2) Membuat alkohol $70 \%$ dengan cara mencampurkan alkohol $96 \%$ sebanyak $416,665 \mathrm{ml}$ dan akuades sebanyak $500 \mathrm{ml}$ aduk bahan hingga tercampur merata. (3) Alkohol $70 \%, \quad \mathrm{H}_{2} \mathrm{O}_{2} \quad 3 \%$ dan gliserol $98 \%$ dimasukan ke dalam beaker gelas kemudian aduk hingga bahan tercampur 
merata. (4) Hand sanitizer dengan bahan kimia siap dikemas.

\section{Proses Pembuatan Hand Sanitizer dengan Bahan Alami}

Proses pembuatan hand sanitizer dengan bahan alami adalah (1) Kulit tanaman lidah buaya dibersihkan kotoran, dikupas kulitnya untuk diambil bagian dagingnya dan diblender kemudian disaring untuk diambil ekstraknya (gel aloe vera) (2) Alkohol $70 \%$ sebanyak $750 \mathrm{ml}$; gel aloe vera sebanyak $230 \mathrm{ml}$ dan esensial oil sebanyak $20 \mathrm{ml}$ diukur dengan gelas ukur dimasukan kedalam beaker gelas kemudian aduk hingga bahan tercampur merata. (4) Hand sanitizer dengan bahan alami siap dikemas.

\section{Pembiakan Bakteri}

Pembiakan bakteri dilakukan dengan cara menginokulasikan bakteri stock Escherichia coli pada media padat Nutrient Agar menggunakan jarum ose dan diinkubasi selama 24 jam pada suhu $37^{\circ} \mathrm{C}$ atau suhu kamar. (Fatisa, 2013).

\section{Uji Daya Hambat Bakteri}

Metode yang digunakan pada uji daya hambat bakteri Escherichia coli pada produk hand sanitizer dilakukan dengan menggunakan metode difusi agar menggunakan kertas cakram (paper disc) berdiameter $6 \mathrm{~mm}$. Uji daya hambat ini dilakukan sebanyak 3 (tiga) kali pengulangan, dengan langkahlangkah sebagai berikut: (1) Bakteri aktif pada media padat dipanen, (2) Cawan petri steril diisi dengan media Nutrient Agar (NA), biarkan memadat lalu inokulasikan bakteri Echerichia coli dengan metode swab, (3) Setiap sampel diberi 3 buah paper disc secara aseptis, (4) Masing-masing paper disc diambil secara aseptis letakkan diatas media NA yang telah diinkubasi dengan bakteri Escherichia coli, (5) Cawan petri diinkubasi pada suhu $37^{\circ} \mathrm{C}$ selama 24 jam dengan posisi cawan terbalik, (6) Pengamatan dilakukan dengan melihat zona bening di sekitar paper disc yang menunjukkan daerah hambatan pertumbuhan bakteri, (7) Pengukuran zona hambat bakteri dengan menggunakan jangka sorong. Ketentuan perhitungannya, apabila ada diameter zona hambat yang besar dan kecil maka keduanya dijumlah kemudian dibagi dua dan dicatat. Pengukuran dilakukan sebanyak 3 kali dan diambil rata-rata (Prasetyowati, 2012). Pengukuran zona dapat diukur menggunakan rumus :

$$
Z \text { ona }=\frac{(\mathrm{Dv}-\mathrm{Dc})+(\mathrm{Dh}-\mathrm{Dc})}{2}
$$

Keterangan :

Dv $=$ Diameter vertikal

$\mathrm{Dh}=$ Diameter horizontal

Dc $=$ Diameter cakram

\section{Analisis Data}

Hasil pengamatan dianalisis menggunakan uji sidik ragam atau Analysis of Variance (ANOVA) pada $\alpha=$ $5 \%$ dan jika didapatkan hasil yang berbeda nyata maka dilakukan uji lanjut menggunakan Duncan's Multiple Range Test (DMRT) untuk mendapatkan hasil yang terbaik.

\section{HASIL DAN PEMBAHASAN}

Uji Daya Hambat Bakteri

Uji daya hambat bakteri Escherichia coli pada produk hand sanitizer bisa dilihat pada tabel berikut:

Tabel. 2. Hasil Uji Duncan's Multiple Range Test (DMRT) Uji Daya Hambat Bakteri Escherichia Coli Pada Produk Hand Sanitizer

\begin{tabular}{cc}
\hline Perlakuan & Rerata \\
\hline A & $5,63^{\mathrm{a}}$ \\
B & $4,80^{\mathrm{a}}$ \\
C & $6,39^{\mathrm{b}}$ \\
\hline Keterangan : Angka yang di ikuti oleh huruf \\
yang berbeda pada kolom yang sama \\
menunjukkan beda nyata pada taraf $5 \%$.
\end{tabular}


Tabel 2 menunjukkan perlakuan $\mathrm{C}$ (produk hand sanitizer komersial) memiliki daya hambat bakteri Eschericia coli yang paling tinggi sebesar $6,39 \mathrm{~mm}$ dibandingkan dengan perlakuan $A$ (produk hand sanitizer dengan bahan kimia) maupun perlakuan B (produk hand sanitizer dengan bahan alami). Berdasarkan hasil uji analisis sidik ragam (ANOVA) pada $\alpha=5 \%$, perlakuan C (produk hand sanitizer komersial) berpengaruh sangat nyata terhadap uji daya hambat bakteri Escherichia coli. Hasil uji lanjut DMRT pada penelitian ini diperoleh perlakuan terbaik pada sampel $\mathrm{C}$ (produk hand sanitizer komersial), hal ini dikarenakan kualitas bahan yang digunakan pada produk hand sanitizer komersial lebih terjamin yang meliputi konsentrasi, senyawa antimikroba yang digunakan, senyawa penstabil serta teknologi yang digunakan pada saat pembuatan.

\section{KESIMPULAN DAN SARAN}

Berdasarkan pembahasan pada penelitian ini dapat disimpulkan bahwa produk hand sanitizer komersial memiliki daya hambat bakteri Escherichia coli yang lebih besar dibandingkan dengan produk hand sanitizer dengan bahan kimia maupun hand sanitizer dengan bahan alami buatan sendiri. Penelitian lebih lanjut perlu dilakukan dengan variasi konsentrasi dengan tambahan senyawa antimikroba maupun senyawa penstabil yang digunakan.

\section{DAFTAR PUSTAKA}

Aminah Asngad, Aprilia Bagas $\mathrm{R}$, Nopitasari. (2018). Kualitas Gel
Pembersih Tangan

(Handsanitizer) dari Ekstrak

Batang Pisang dengan

Penambahan Alkohol, Triklosan

dan Gliserin yang Berbeda

Dosisnya. Jurnal Bioeksperimen. 4

(2) : 61-70.

Baizuroh. N , Yahdi, Y. K. Dewi, 2021. Uji Kualitas Hand Sanitizer Ekstrak Daun Kunyit (Curcuma Longa Linn). Jurnal Al-Kimiya IImu Kimia dan Terapan Jurusan Kimia Fakultas Sains dan Teknologi UIN Sunan Gunung Djati Bandung. 8 (1).

Fatisa. Y. (2013). Daya Antibakteri Ekstrak Kulit dan Biji Buah Pulasan (Nephelium mutabile) Terhadap Staphylococcus aureus dan Escherichia coli Secara In Vitro. Jurnal Peternakan Program Studi Pendidikan Kimia, Fakultas Tarbiyah dan Keguruan, Universitas Islam Negeri Sultan Syarif Kasim Riau. 10 (1).

Lusiana R. A., D. S. Widodo, L. Suyanti, Gunawan, A. Haris. 2020. Edukasi Pembuatan Hand Sanitizer Berbasis Lidah Buaya pada Masyarakat Desa Harjowinangun, Grobogan. Jurnal Pengabdian Kepada Masyarakat (JPKM) TABIKPUN FMIPA Universitas Lampung. 1 (1).

Nelintong N, Isnaeni, N. E. Nasution. 2015. Aktivitas Antibakteri Susu Probiotik Lactobacilli Terhadap Bakteri Penyebab Diare (Escherichia coli, Salmonella typhimurium, Vibrio cholerae). Jurnal Farmasi dan IImu Kefarmasian Indonesia, 2 (1).

Susanty, T .Y. Hendrawati , W. D. Rusanti, 2020. Pengaruh Penambahan Gel Aloe Vera Terhadap Efektifitas Antiseptik Gel. Jurnal Teknologi Universitas Muhammadiyah Jakarta. 12 (1). 